\title{
Molecular similarity of Drosophila melanogaster alcohol dehydrogenase thermostable alleles from populations on different continents
}

John B. Gibson,

Darryl Reed,

Ann Verona Wilks and

Chengshan Jiang
Molecular and Population Genetics Group,

Research School of Biological Sciences,

The Australian National University, P.O. Box 475, Canberra City, A.C.T. 2601, Australia.

Allele specific oligonucleotide probes have been used to show that DNA, amplified by the polymerase chain reaction, from eleven thermostable $A d h$ alleles extracted from populations on different continents contains the triplet TCC, which distinguishes $A d h^{F C h D}$ (Fast Chateau Douglas) from $A d h^{F}$ (Fast). The molecular similarity of Adh thermostable alleles suggests that they had a common origin, and it is argued that the mutation probably occurred in China where high frequencies of $A d h^{F C h D}$ are found.

\section{INTRODUCTION}

Most natural populations of Drosophila melanogaster are polymorphic for two electrophoretically detectable alleles at the alcohol dehydrogenase (ADH; EC 1.1.1.1) locus (Adh) (Vigue and Johnson, 1973; Oakeshott et al., 1982; Singh et al., 1982). The proteins encoded by these two alleles, $\left(A d h^{S}\right.$ and $A d h^{F}$ ) differ by a single amino acid at residue 192, with lysine in ADH-S replaced by threonine in ADH-F (Thatcher, 1980). Within the ADH-F electrophoretic class a third category of variant has been identified because the ADH is very much more thermostable than either ADH-F or ADH-S. These thermostable variants were first found in a laboratory stock (Thörig et al., 1975) and subsequently at low but polymorphic frequencies in natural populations in North America (Milkman, 1976; Sampsell, 1977), Australia (Lewis and Gibson, 1978; Wilks et al., 1980), the Canary Islands (Hernandez et al., 1986) and China (Jiang et al., 1989). Comparisons of other biochemical properties of the $A d h$ thermostability variants with those of ADH-S and ADH-F have shown that the thermostable variants tend to be intermediate with respect to the amounts of $\mathrm{ADH}$ protein and they have a secondary alcohol/primary alcohol activity ratio characteristic of ADH-S rather than ADH-F (Lewis and Gibson, 1978; Gibson et al., 1980; Chambers et al., 1981b; Gibson et al., 1982b; Sampsell and Steward, 1983; Jiang et al., 1989).

Chambers et al. (1981a) determined the amino acid sequence of 70 per cent of the protein produced by one of these thermostable variants, Adh Fast Chateau Douglas ( $A d h^{F C h D}$ ) extracted from an Australian population, and showed that it differed from ADH-F by the substitution of serine for proline at residue 214. Nucleotide sequence analysis of $A d h^{F C h D}$ has confirmed this structure (Collet, 1988) by showing that the relevant codon is TCC, compared to CCC in $A d h^{F}$ alleles (Kreitman, 1983).

The similarities in biochemical properties of the $A d h^{F}$ thermostable variants prompt the speculation that they all share the same mutation and are perhaps derived from a single mutational event. Although it seems very likely that the substitution of serine for proline in $A d h^{F C h D}$ is the cause of the increased heat stability of ADH-FChD protein it is possible that in other thermostable variants a different mutation has brought about increases in thermostability. Thus it is possible that the $A d h$ thermostable alleles from geographically widely separated populations, or even within the same population, are molecularly heterogeneous.

To test whether $A d h$ thermostable variants isolated from populations on different continents between 1971 and 1986 all have the nucleotide sequence TCC, which is found in $A d h^{F C h D}$ at posi- 
tion 1555-1557 we have used allele specific oligonucleotides (ASO) to probe DNA from thermostable and normal $A d h^{F}$ alleles. A similar experimental approach has been used to identify variants of $\beta^{\text {s }}$-globin alleles (Conner et al., 1983) and $\alpha_{1}$ antitrypsin deficiency alleles (Kidd et al., 1983), and to investigate polymorphism at the HLA-DQ $\alpha$ locus (Saiki et al., 1986) in human material.

\section{MATERIALS AND METHODS}

The population origins of the $A d h$ thermostable variants compared in this study are listed in table 1. In addition a number of single allele $A d h^{F}$ lines and an $A d h^{S}$ line, derived from North American, Australian and Chinese populations, were used as controls. All of the alleles used have been maintained as homozygotes in mass cultures since their isolation from natural populations.

Table 1 Geographical origins of alcohol dehydrogenase alleles encoding heat resistant $\mathrm{ADH}$

\begin{tabular}{|c|c|}
\hline Continent & Alleles \\
\hline North America & $\begin{array}{l}\text { Sf } 1 \text {-Cedar Rapids, Iowa, 1975 } \\
\text { (Sampsell and Steward, 1983) } \\
\text { Si44-Cedar Rapids, Iowa, 1975 } \\
\text { (Sampsell and Steward, 1983) } \\
\text { AR72-Tempe, Arizona, 1976. } \\
\text { (Sampsell and Steward, 1983) } \\
\text { CS47-Chicago, Illinois, 1980. } \\
\text { (Sampsell and Steward, 1983) } \\
\text { BG27-Bowling Green, Ohio, } 1981 . \\
\text { (Sampsell and Steward, 1983) }\end{array}$ \\
\hline Europe* & $\begin{array}{l}71 k \text {-isolated in } 1971 \text { from a } \\
N^{8} / \text { delta-49 laboratory stock held in } \\
\text { Utrecht (Thörig et al., 1975) }\end{array}$ \\
\hline China & $\begin{array}{l}\text { H15-Haikou 1986. (Jiang et al., 1989) } \\
\text { H20-Haikou 1986. (Jiang et al., 1989) } \\
\text { G15-Guangzhou 1986. (Jiang et al., } \\
\text { 1989) }\end{array}$ \\
\hline Australia & $\begin{array}{l}\text { ChD12-Chateau Douglas, Segenhoe, } \\
\text { NSW, 1975. (Lewis and Gibson, 1978) } \\
\text { Cr14-Craigmoor, NSW, } 1980 . \\
\text { (Gibson et al., 1982b) }\end{array}$ \\
\hline
\end{tabular}

* The $N^{8} /$ delta- 49 stock probably originated in North America.

To reduce non-specific hybridisation to the allele specific oligonucleotide probes $(A F$ and $A F D$, see table 2), which was found in preliminary experiments to occur with genomic DNA, and to obviate the need to clone each of the thermostable alleles, we have used synthetic oligonucleotide
Table 2 DNA sequences of the synthetic oligonucleotide probes $A F$ and $A F D$. The single nucleotide change distinguishing $A d h^{F C h D}$ from $A d h^{F}$ is underlined

\begin{tabular}{lll}
\hline Gene & Probe & DNA sequence \\
\hline$A d h^{F}$ & $A F$ & 5' CCC ACC CAG CCC TCG TTG G 3' \\
$A d h^{F C h D}$ & $A F D$ & 5' CCC ACC CAG TCC TCG TTG G 3'
\end{tabular}

primers and the polymerase chain reaction (PCR) to amplify a 368 bp region of the $A d h$ gene, which includes the nucleotides at position 1555-1557 specifying the proline or serine residue (fig. 1). Genomic DNA (approximately $1 \mu \mathrm{g}$ ), prepared as described by Chia et al. (1985), was amplified using 2 units of Taq DNA polymerase as described by Saiki et al. (1988). The amplification reaction mixture included the target DNA and $50 \mathrm{pmol}$ of each of the primers

JG5 (5'-GTGGTCAACTTCACCAGCTC-3') and

JG6 (5'-CTTCTTAGATGCCGGAGTCC-3') which encompass a region of the $A d h$ gene from nucleotide 1320-1687 (Kreitman, 1983) (fig. 1). The amplification reaction, carried out in $0.5 \mathrm{ml}$ microcentrifuge tubes, was repeated for 35 cycles-

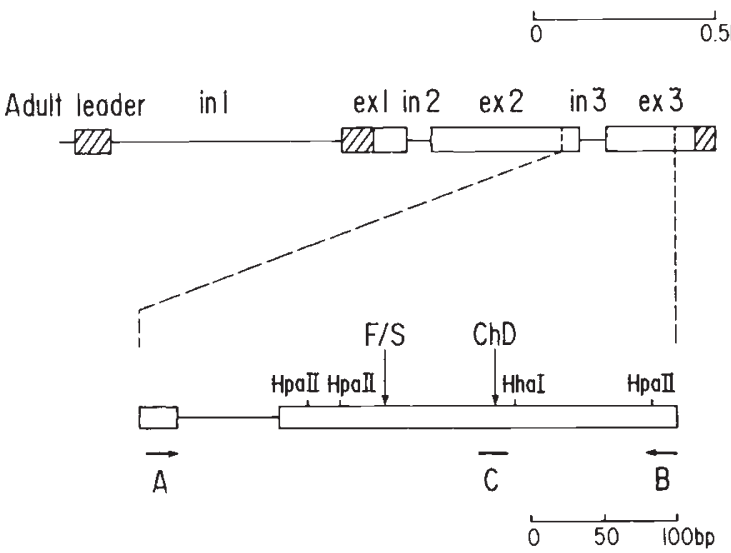

Figure 1 The structure of the $A d h$ gene in $D$. melanogaster showing the relative sizes of the three exons and three introns. The non-translated regions are hatched. The $368 \mathrm{bp}$ region amplified by the PCR is drawn in more detail. The sites of the Lys $\leftarrow \rightarrow$ Thr substitution distinguishing $A d h^{s}$ and $A d h^{F}$ and the Ser $\leftarrow \rightarrow$ Pro substitution in $A d h^{F C h D}$ are indicated by vertical arrows. The positions of some restriction endonuclease sites are shown. The positions of the two amplification primers used in the PCR reaction are indicated at $A$ and $B$ and the region to which the oligonucleotide probes $A F$ and $A F D$ hybridise is shown at C. 
a cycle consisted of 1 min for denaturation of DNA at $94^{\circ} \mathrm{C}, 2 \mathrm{~min}$ for annealing of the DNA and primers at $50^{\circ} \mathrm{C}$ and $3 \mathrm{~min}$ for primer extension at $72^{\circ} \mathrm{C}$--using a Perkin-Elmer Cetus Thermal Cycler.

The amplified DNA $(5 \mu \mathrm{l})$ was denatured in $0.4 \mathrm{M} \mathrm{NaOH}$ for $10 \mathrm{~min}$ and then transferred to a Zeta-Probe membrane in the Bio-Rad slot blotting apparatus, using the manufacturer's instructions. The blotted membrane was rinsed in $2 \times \mathrm{SSC}$, airdried and then sandwiched between two sheets of Whatman 3MM filter paper soaked in distilled water. The membrane/filter paper sandwich was sealed in a plastic bag with the prehybridisation mixture which contained $5 \times \mathrm{SSC}, 20 \mathrm{mM}$ $\mathrm{NaH}_{2} \mathrm{PO}_{4} p \mathrm{H} 7 \cdot 0,4$ per cent SDS, $10 \times$ Denhardt's solution, 10 per cent dextran sulfate and denatured herring sperm DNA at $100 \mu \mathrm{g} / \mathrm{ml}$, and incubated for $1 \mathrm{~h}$ at $59^{\circ} \mathrm{C}$. One of the allele specific oligonucleotide probes $(A F$ or $A F D)$, labelled with $[\gamma$ $\left.{ }^{32} \mathrm{P}\right] \mathrm{dATP}$, was then added to the plastic bag and hybridised orernight at $59^{\circ} \mathrm{C}$. The membrane was washed at $59^{\circ} \mathrm{C}$ for 30 mins in a solution containing $3 \times \mathrm{SSC}, 25 \mathrm{mM} \mathrm{NaH} \mathrm{PO}_{4} \mathrm{pH} \mathrm{7 \cdot 5,5}$ per cent SDS, $10 \times$ Denhardt's solution, and then at the same temperature for 30 mins in $1 \times$ SSC with 1 per cent SDS. The membranes were blotted with Whatman $3 \mathrm{MM}$ filter paper, wrapped in plastic film and exposed to Kodak film (XRP-1) for 3 hours at $-20^{\circ} \mathrm{C}$.

For Southern analyses the amplified DNA samples were digested with HhaI and electrophoresed on a 2 per cent agarose mini gel at $7 \mathrm{v} / \mathrm{cm}$ for $90 \mathrm{~min}$ at room temperature. The DNA fragments were transferred from the agarose gels to Zeta-Probe membranes by alkaline blotting $(0.4 \mathrm{M} \mathrm{NaOH})$. The membranes were rinsed in $2 \times \mathrm{SSC}$, blotted dry and baked at $80^{\circ} \mathrm{C}$ for $45 \mathrm{~min}$. The membranes were then wetted in distilled water, sandwiched between two sheets of filter paper and treated as described above.

The oligonucleotides were synthesised on an Applied Biosystems 380B DNA synthesiser.

\section{RESULTS}

The DNA sequences of the oligonucleotides used as probes are shown in table 2 . Probe $A F D$ was designed to be a perfect match to $A d h^{F C h D}$ and the mutation distinguishing this allele from $A d h^{F}$ was placed close to the middle of the sequence of 19 nucleotides to maximise the thermal instability of mismatch hybridisation (Wallace et al., 1981).
Based on the length and $\mathrm{G}: \mathrm{C}$ content of the two oligonucleotides, the $T_{m} \mathrm{~s}$ for the probes were calculated to be $64^{\circ} \mathrm{C}$ for $A F D$ and $66^{\circ} \mathrm{C}$ for $A F$. Theoretically a perfectly matched oligonucleotideDNA duplex would be stable at $5^{\circ} \mathrm{C}$ below the $T_{m}$ value, and a further $5^{\circ} \mathrm{C}$ reduction would be necessary to maintain hybrid stability for every mismatched base pair. (Wallace et al., 1981). Preliminary experiments indicated that in hybridisations carried out at $54^{\circ} \mathrm{C}$, probe $A F$ hybridised with similar intensities to DNA from $A d h^{F}$ and $A d h^{F C h D}$. However, at $59^{\circ} \mathrm{C}$ both probes discriminated between the $A d h^{F C h D}$ and $A d h^{F}$ control alleles (fig. 2).
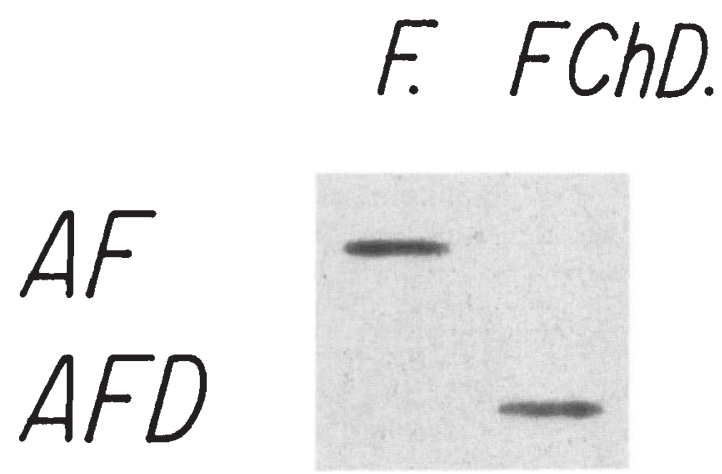

Figure 2 PCR amplified DNA from $A d h^{F}$ and $A d h^{F C h D}$ control alleles blotted onto a Zeta-Probe membrane and probed with the oligonucleotides $A F$ and $A F D$ (see text); hybridisation was carried out at $59^{\circ} \mathrm{C}$.

The fidelity of the polymerase chain reaction was checked by digesting samples of the amplified DNA with two restriction endonucleases: Hha I which was expected to generate fragments of 248 and $120 \mathrm{bp}$ and Hpa II which cuts at three sites in the region giving fragments of $114,27,213$ and $14 \mathrm{bp}$ (fig. 1). In all cases investigated, the amplified DNA migrated as a single band of the size expected and the digestion products conformed to the sizes expected from the standard sequence (Hha I digestion shown in fig. 3 (a) and (d)), indicating that there was little non-specific amplification and that none of the alleles tested had any detectable insertions or deletions ( $>20 \mathrm{bp}$ ) in the amplified region.

Southern blots prepared from Hha I digests of amplified DNA from thermostable $A d h^{F}$ alleles and from control $A d h^{F}$ and $A d h^{S}$ alleles were probed with $A F D$ and $A F$. These results show that $A F$ hybridised to the 248 bp Hha I fragment of the $A d h^{F}$ alleles but not to DNA from the 

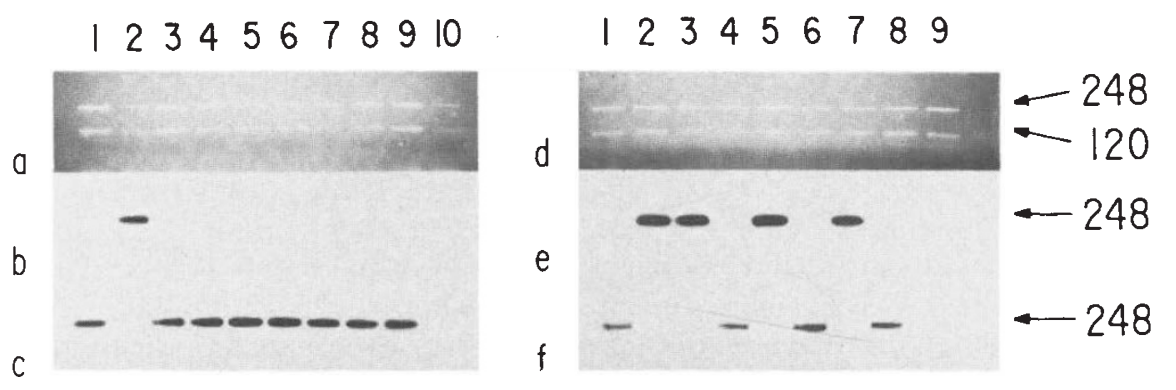

Figure 3 PCR amplified DNA digested with Hha I: (a) and (d) after electrophoresis on agarose gel, (b), (c), (e) and (f) similar gels blotted on a Zeta-Probe membrane and probed at $59^{\circ} \mathrm{C}$; for (b) and (e) the probe was $A F$, for (c) and (f) the probe was $A F D$. Adh variants in lanes 1-10, in (a), (b) and (c): $F C h D 12, F, \underline{C S 47}, \underline{S i 44}, \underline{B G 27}, \underline{A R 72}, \underline{S f 1}, \underline{71 K}, \underline{F C r 14}, S$; in lanes $1-9$ in (d), (e) and (f): $F C h D 12, F, G 1, \underline{G 15}, H 6, \underline{H 15}, H 36, \underline{H 20}, S$.

The thermostable alleles are underlined, $F$ is a control $A d h^{F}$ and $S$ is a control $A d h^{S}$, the other variants are all electrophoretically "fast". The origins of the thermostable $A d h$ alleles are given in table 1; $G 1$ was extracted from Guangzhou and $H 6$ and H36 from Haikou.

thermostable $A d h$ alleles or the $A d h^{S}$ allele (fig. 3(b) and (e)). The probe $A F D$ hybridised to the same Hha I fragment, but only to DNA from $A d h$ alleles encoding heat resistant $\mathrm{ADH}$; it did not hybridise to DNA from the $A d h^{F}$ or the $A d h^{S}$ control alleles (fig. 3(c) and (f)). The $A F D$ probe hybridised to heat resistant $A d h$ alleles from each continent; in no case did the $A F D$ probe fail to hybridise to a heat resistant $A d h$ allele.

\section{DISCUSSION}

The results show that under stringent hybridisation conditions the two synthetic oligonucleotides discriminate between $A d h^{F}$ and $A d h^{F C h D}$ and identify similar thermostable alleles. Neither probe hybridised to $A d h^{S}$ DNA under these stringency conditions (although both do when the stringency is relaxed). The collated data on the nucleotide sequences of six $A d h^{S}$ alleles and six $A d h^{F}$ alleles (table 3 ) indicate that the $A F$ probe is likely to be a perfect match to $A d h^{F}$ alleles but not to all $A d h^{S}$ alleles. These data suggest that the $A d h^{S}$ allele we used as a control (which was isolated from the same Tasmanian population as one of the $A d h^{F}$ controls) has the sequence CCA at position 15551557 and thus has at least one mismatch with both probes.

The Southern blots show that thermostable Adh alleles isolated over a fifteen year period from eight different populations on three continents are indistinguishable in these experiments from $A d h^{F C h D}$. It therefore is highly likely that all of these thermostable variants have the DNA sequence TCC and have serine at residue 214 as does ADH-FChD.
The highly consistent relationship between the relatively high thermostability of the ADH protein and the substitution of serine for proline at residue 214 in a series of alleles with a variety of genetic backgrounds indicates that protein structural changes accompanying this substitution cause the change in thermostability (Chambers et al., 1981a).

The molecular similarity of the Adh thermostable alleles lends support to the hypothesis (Jiang

Table 3 Amino acid and DNA sequences of alcohol dehydrogenase alleles in the region covered by the synthetic oligonucleotide probes $A F$ and $A F D$ (variation has not been reported in the flanking sixteen nucleotides)

\begin{tabular}{|c|c|c|c|}
\hline \multirow[b]{2}{*}{ Origin of allele } & \multicolumn{3}{|c|}{ Allele sequenced } \\
\hline & $A d h^{S}$ & $A d h^{F}$ & $A d h^{F C h D}$ \\
\hline U.S.A. (Seattle)* & $\begin{array}{l}\text { Pro } \\
\text { CCA }\end{array}$ & $\begin{array}{l}\text { Pro } \\
\mathrm{CCC}\end{array}$ & - \\
\hline U.S.A. (Palm Beach) ${ }^{*}$ & $\begin{array}{l}\text { Pro } \\
\text { CCA }\end{array}$ & $\begin{array}{l}\text { Pro } \\
\mathrm{CCC}\end{array}$ & - \\
\hline U.S.A. (Palm Beach) ${ }^{*}$ & $\begin{array}{l}\text { Pro } \\
\text { CCA }\end{array}$ & - & - \\
\hline France (Bully)* & $\begin{array}{l}\text { Pro } \\
\text { CCA }\end{array}$ & $\begin{array}{l}\text { Pro } \\
\text { CCC }\end{array}$ & 一 \\
\hline Africa (Burindi) ${ }^{*}$ & $\begin{array}{l}\text { Pro } \\
\text { CCA }\end{array}$ & $\begin{array}{l}\text { Pro } \\
\mathrm{CCC}\end{array}$ & - \\
\hline Japan (Ishigaki)* & $\begin{array}{l}\text { Pro } \\
\mathrm{CCC}\end{array}$ & $\begin{array}{l}\text { Pro } \\
\text { CCC }\end{array}$ & - \\
\hline Australia (Huonville) ${ }^{\dagger}$ & - & $\begin{array}{l}\text { Pro } \\
\mathrm{CCC}\end{array}$ & - \\
\hline Australia (Segenhoe) $)^{\ddagger}$ & - & 一 & $\begin{array}{l}\text { Ser } \\
\text { TCC }\end{array}$ \\
\hline
\end{tabular}

Data from * Kreitmann (1983); † Gibson and Wilks (unpublished); $\ddagger$ Collet (1988). 
et al., 1989) that they are derived from the same mutation. The amino acid and nucleotide sequences of $A d h^{F C h D}, A d h^{F}$ and $A d h^{S}$ alleles show that $A d h^{F C h D}$ was derived from $A d h^{F}$. There is evidence that $A d h^{S}$ is ancestral to $A d h^{F}$ as the ADH's of $D$. simulans and $D$. mauritiana both have lysine at residue 192 rather than threonine (Ashburner et al., 1984). Estimates of the age of the $A d h^{F} / A d h^{S}$ polymorphism in $D$. melanogaster range from 610,000 years to $3 \cdot 5 \mathrm{Myr}$ (Stephens and Nei, 1985) with those authors preferring $1 \mathrm{Myr}$ as the best estimate available for the time of the $A d h^{F}$ mutation. Based on the relatively low level of sequence variation between a single $A d h^{F C h D}$ and five $A d h^{F}$ haplotypes Collet (1988) estimated the time for the divergence of $A d h^{F C h D}$ from $A d h^{F}$ as 260,000 to 473,000 years. The proline/serine change does not occur in other members of the species group (Bodmer and Ashburner, 1984), so the region is not a "hot spot" for mutational change.

The population distribution of $A d h^{F C h D}$ is intriguing and relevant to hypotheses about its origin. Far fewer natural populations have been scored for $A d h$ thermostable alleles than for $A d h^{F}$, but in the data that are available the highest frequency of $A d h^{F C h D}$ is in southern China where it reaches 30 per cent (Jiang et al., 1989). Although the allele occurs at low frequency in the Canary Islands (Hernández et al., 1986) it has not so far been reported from the African continent where the melanogaster subgroup originated (Lemeunier et al., 1985; Lachaise et al., 1988).

In populations sampled in North America and Australia, where most data are available, the frequencies of $A d h^{F}$ thermostable alleles tend to be less than 5 per cent (Sampsell, 1977; Wilks et al., 1980). The highest frequencies occur in populations with intermediate levels of $A d h^{F}$, and this pattern of distribution does not appear to track any climatic variable. The exceptionally high frequencies in southern China are not matched at sites elsewhere with similar climates. This leads us to suggest that the present geographical distribution of $A d h^{F C h D}$ could have arisen if the mutation first occurred in southern China and from there dispersed. However, as the mutation is estimated to have occurred 260,000 to 473,000 years ago, this would imply that $D$. melanogaster colonised the Eurasian continent very much earlier than the minimum of 6500 to 9500 years ago suggested by Lachaise et al. (1988). It is believed that $D$. melanogaster probably became a colonist of North America (Sturtevant, 1920) and Australia in the past two hundred years (Jiang et al., 1989).
Further speculation on the origin and geographical distribution of $A d h^{F C h D}$ will benefit from more extensive data on population frequencies in Africa, in other parts of Asia, and particularly in South America where no data are presently available. It will then be possible to compare the complete nucleotide sequences of a number of $A d h^{F C h D}$ thermostable alleles with those of $A d h^{F}$ to discern their lineages and obtain further evidence on the time of occurrence of the $A d h^{F C h D}$ mutation. Whether $A d h^{F C h D}$ alleles turn out to have had a single or multiple origin, the evidence that heat resistant alleles are molecularly similar will facilitate population comparisons of $A d h$ frequencies (Gibson et al., 1982a).

Acknowledgements We are very grateful to Dr B. Sampsell for giving us her samples of $\boldsymbol{A d h}$ alleles isolated from populations in North America and to Huazhong Chen and Professor C. C. Tan for sending us material from the Peoples' Republic of China. We thank Anh Cao for excellent technical assistance and Garry Mayo for synthesising the oligonucleotides. C.J. acknowledges the financial support of the State Education Commission of the Peoples' Republic of China and an Australian National University Postgraduate Scholarship.

\section{REFERENCES}

ASHBURNER, M., BODMER, M. AND LEMEUNIER, F. 1984. On the evolutionary relationships of Drosophila melanogaster. Develop. Genet., 4, 295-312.

BODMER, M. AND ASHBURNER, M. 1984. Conservation and change in the DNA sequences coding for alcohol dehydrogenase in sibling species of Drosophila. Nature, 309, 425-430.

CHAMBERS, G. K., LAVER, W. G., CAMPBELL, S. AND GIBSON, J. B. $1981 a$. Structural analysis of an electrophoretically cryptic alcohol dehydrogenase variant from an Australian population of Drosophila melanogaster. Proc. Natl Acad. Sci. USA, 78, 3103-3107.

CHAMBERS, G. K., WILKS, A. V. AND GIBSON, J. B. 1981 b. An electrophoretically cryptic alcohol dehydrogenase variant in Drosophila melanogaster. III. Biochemical properties and comparison to the common enzyme forms. Aust. J. Biol. Sci., 34, 625-637.

CHIA, W., SAVAKIS, C., KARP, R., PELHAM, H. AND ASHBURNer, M. 1985. Mutation of the Adh gene of Drosophila melanogaster containing an internal tandem duplication. J. Mol. Biol., 186, 679-688.

COLLET, c. 1988. Recent origin for a thermostable alcohol dehydrogenase allele of Drosophila melanogaster. J. Mol. Evol., 27, 142-146.

CONNER, B. J., REYES, A. A., MORIN, C., ITAKURA, K., TEPLITZ, R. L. AND BRUCE WALLACE, R. 1983. Detection of sickle cell $\beta^{\text {s }}$-globin allele by hybridization with synthetic oligonucleotides. Proc. Natl Acad. Sci. USA, 80, 278-282.

GIBSON, J. B., ANDERSON, D. G. AND WILKS, A. V. $1982 a$. Electrophoretic variability at the alcohol dehydrogenase locus in Drosophila melanogaster. Genetics, 101, 331-333. 
GIBSON, J. B., CHAMBERS, G. K., WILKS, A. V. AND OAKESHOTT, J. G. 1980. An electrophoretically cryptic alcohol dehydrogenase variant in Drosophila melanogaster. I. Activity ratio, genetic localization and comparison with two other thermostable variants. Aust. J. Biol. Sci., 33, 479-489.

GIBSON, J. B., WILKS, A. V. AND CHAMBERS, G. K. 1982 b. Genetic variation at the alcohol dehydrogenase locus in Drosophila melanogaster: A third ubiquitous allele. Experientia, 38, 653-654.

HERNÁNDEZ, M., PADRÓN, G. AND CABRERA, V. M. 1986. Persistence of an alcohol dehydrogenase thermostable variant in a natural population of Drosophila melanogaster. Genet. Res. Camb., 47, 143-146.

JIANG, C., GIBSON, J. B. AND CHEN, H. 1989. Genetic differentiation in populations of Drosophila melanogaster from the Peoples' Republic of China: comparison with patterns on other continents. Heredity, 62, 193-198.

KIDD, V. J., BRUCE WALLACE, R., ITAKURA, K. AND WOO, S, L. C. 1983. $\alpha_{1}$-Antitrypsin deficiency detection by direct analysis of the mutation in the gene. Nature, 304, 230-234.

KREITMAN, M. 1983. Nucleotide polymorphism at the alcohol dehydrogenase locus of Drosophila melanogaster. Nature, 304, 412-417.

LACHAISE, D., CARIOU, M., DAVID, J. R., LEMEUNIER, F., TSACAS, L. AND ASHBURNER, M. 1988. Historical biogeography of the Drosophila melanogaster species subgroup. Evol. Biol., 22, 159-225.

LEMEUNIER, F., DAVID, J. R., TSACAS, L. AND ASHBURNER, M. 1985. The Drosophila melanogaster species group. In Ashburner, M., Carson, H. L. and Thompson, J. M. (eds) The Genetics and Biology of Drosophila, Academic Press, London.

LEWIS, N. AND GIBSON, J. B. 1978. Enzyme protein amount variation in natural populations. Biochem. Genet., 16, 159170.

MILKMAN, R. 1976. Further evidence of thermostability variation within electrophoretic mobility classes of enzymes. Biochem. Genet, 14, 383-387.

OAKESHOTT, J. G., GIBSON, J. B., ANDERSON, P. R., KNIBB, W. R., ANDERSON, D. G. AND CHAMBERS, G. K. 1982. Alcohol dehydrogenase and glycerol-3-phosphate dehydrogenase clines in Drosophila melanogaster on different continents. Evolution, 36, 86-96.

SAIKI, R. K., BUGAWAN, T. L., HORN, G. T., MULLIS, K. B. AND ERLICH, H. A. 1986. Analyses of amplified $\beta$-globin and HLA-DQ $\alpha$ DNA with allele-specific oligonucleotide probes. Nature, 324, 163-166.
SAIKI, R. K., GELFAND, D. H., STOFFEL, S., SCHARF, S. J., HIGUCHI, R., HORN, G. T., MULLIS, K. B. AND ERLICH, H..A. 1988. Primer-directed enzymatic amplification of DNA with a thermostable DNA polymerase. Science, 239, 487-491,

SAMPSELL, B. 1977. Isolation and genetic characterization of alcohol dehydrogenase thermostability variants occurring in natural populations of Drosophila melanogaster. Biochem. Genet., 15, 971-988.

SAMPSELL, B. AND STEWARD, E. 1983. Alcohol dehydrogenase thermostability variants in Drosophila melanogaster: Comparison of activity ratios and enzyme levels. Biochem. Genet., 21, 1071-1087.

SINGH, R. S., HICKEY, D. A. AND DAVID, J. R. 1982. Genetic differentiation between geographically distant populations of Drosophila melanogaster. Genetics, 101, 235-256.

STEPHENS, J. C. AND NEI, M. 1985. Phylogenetic analysis of polymorphic DNA sequences at the Adh locus of Drosophila melanogaster and its sibling species. J. Mol. Evol., 22, 289-300.

Sturtevant, A. H. 1920. Genetic studies on Drosophila simulans. I. Introduction. Hybrids with $D$. melanogaster. Genetics, 5, 488-500.

THATCHER, D. R. 1980. The complete amino acid sequence of three alcohol dehydrogenase alleloenzymes $\left(A d h^{n 11}, A d h^{s}\right.$ and $A d h^{U F}$ ) from the fruitfly Drosophila melanogaster. Biochem. J., 187, 875-883.

THÖRIG, G. E. W., SCHOONE, A. A. AND SCHARLOO, W. 1975. Variation between electrophoretically identical alleles at the alcohol dehydrogenase locus in Drosophila melanogaster. Biochem. Genet., 13, 721-731.

VIGUE, C. L. AND JOHNSON, F. M. 1973. Isozyme variability in species of the genus Drosophila. VI. Frequency-propertyenvironment relationships of allelic alcohol dehydrogenase in D. melanogaster. Biochem. Genet., 9, 213-227.

WALLACE, R. B., SCHÖLD, M., JOHNSON, M. J., DEMBEK, P. AND ITAKURA, K. 1981. Oligonucleotide directed mutagenesis of the human $\beta$-globin gene: a general method for producing specific point mutations in cloned DNA. Nuc. Acid. Res., 9, 3647-3656.

WILKS, A. V., GIBSON, J. B., OAKESHOTT, J. G. AND CHAMBERS, G. K. 1980. An electrophoretically cryptic alcohol dehydrogenase variant in Drosophila melanogaster. II. Postelectrophoresis heat treatment screening of natural populations. Aust. J. Biol. Sci., 33, 575-585. 